Krystyna Stefańska

\title{
Pojęcia „nieruchomość rolna” i „gospodarstwo rolne” w ujęciu kodeksu cywilnego i ich znaczenie dla legislacji prawnorolnej
}

1. Zdefiniowanie w 1990 roku w kodeksie cywilnym ${ }^{1}$ podstawowych pojęć prawa rolnego, tzn. nieruchomości rolnej i gospodarstwa rolnego nie można uznać za nieprzemyślany czy przypadkowy zabieg legislacyjny. Wprowadzenie tych pojęć do kodeksu cywilnego (art. 461 i art. 553) było logiczną konsekwencją dokonujących się, zwłaszcza po 1982 r., ${ }^{2}$ zmian zmierzających w kierunku zwiększania stopnia ochrony własności rolniczej, ograniczania wcześniejszej ingerencji administracyjnej. Dlatego też postulat zdefiniowania wspomnianych pojęć w kodeksie cywilnym pojawił się już wraz ze zmianami przyjmowanymi po 1982 roku w odniesieniu do przeniesienia własności nieruchomości rolnych. S. Wójcik wskazywał, że brak tych definicji w kodeksie cywilnym osłabiał gwarancje ustawowe, jakie powinna mieć indywidualna własność rolnicza także w zakresie przeniesienia własności nieruchomości rolnej ${ }^{3}$. Autor podkreślał, że o zakresie działania ustawy powinna decydować ustawa, a nie akt prawny niższego rzędu ${ }^{4}$. Regulacja przyjęta w tym zakresie w wyniku nowelizacji kodeksu cywilnego w 1990 roku wychodziła więc naprzeciw zgłaszanym w tym względzie oczekiwaniom. S. Wójcik, już po wspomnianych zmianach w 1990 roku przypominał, że wcześniejsze powierzenie Radzie Ministrów określenia pojęć „,nieruchomość rolna” czy „gospodarstwo rolne” z góry zakładało, że zakres obrotu nieruchomościami rolnymi będzie ulegał zmianom, że była to regulacja mniej stabilna niż regulacja ściśle ustawowa ${ }^{5}$.

2. W momencie uchwalania w 1964 r. Kodeksu cywilnego nie przejęto do niego pojęcia „nieruchomości rolnej” z ustawy z 13 VII 1957 r. o obrocie nierucho-

$1 \quad$ Ustawa z dnia 28. VII 1990 r. O zmianie ustawy Kodeks cywilny (Dz.U. Nr 55, poz. 321).

2 Por. np. ustawę z dnia 26111982 r. o zmianie ustawy - kodeks cywilny oraz o uchyleniu ustawy o uregulowaniu własności gospodarstw rolnych (Dz.U. Nr 11, poz. 81); art. 51 ustawy z dnia 26111982 r. o ochronie gruntów rolnych i leśnych (Dz.U. Nr 11, poz. 79).

3 S. Wójcik, Przeniesienie własności nieruchomości rolnej między osobami fizycznymi w świetle zmian kodeksu cywilnego, Nowe Prawo 1983 r., z. 1, s. 19.

4 Tamże, s. 44.

5 S. Wójcik, Obrót nieruchomościami i gospodarstwami rolnymi między osobami fizycznymi - próba oceny i wnioski de lege ferenda, (w:) Księga Pamiątkowa. I Kongres Notariuszy Rzeczypospolitej Polskiej, Kluczbork-Poznań 1993, s. 322. 
mościami rolnymi ${ }^{6}$, chociaż w kodeksie cywilnym uregulowano podstawowe zasady obrotu nieruchomościami rolnymi. Pojęcie „nieruchomość rolna” zostało zdefiniowane w rozporządzeniu RM z 28 XI 1964 r. ${ }^{7}$ Używanie jednak w kodeksie cywilnym pojęcia „,nieruchomość rolna”, jak np. w art.160, 161, 163 czy 166 kc. oznaczało silne związanie obrotu prawnorolnego z prawem prywatnym. Wskazywano równocześnie, że określenie „nieruchomość rolna” używane w cytowanych wyżej przepisach kodeksu cywilnego występowało w tym samym znaczeniu co w art. $46 \S$ 1 kc. J.St. Piątowski akcentowat, że dla pojęcia nieruchomości z art. $46 \S 1$ kc. istotne są dwa kryteria: fizyczne wyodrębnienie danego obszaru gruntów oraz kryterium prawne oparte na prawie własności, zaznaczając, że to drugie ma podstawowe znaczenie $^{8}$. Aczkolwiek w latach następnych po wydaniu kodeksu cywilnego nastąpiło szereg zmian w obrocie nieruchomościami rolnymi dokonywanych w drodze pozakodeksowej, to kodeks cywilny pozostawał aktem prawnym podstawowym w tej dziedzinie i dlatego też wszelkie zmiany odbierane były zwłaszcza jako ingerencja w prawo własności regulowane przez kodeks cywilny. Dlatego tak uzasadniony był wspomniany postulat S. Wójcika, aby pojęcia ,nieruchomość rolna” czy „gospodarstwo rolne" znalazły się w kodeksie cywilnym, by zwiększać gwarancje dla własności rolniczej.

Znaczenie kodeksu cywilnego dla regulacji prawnorolnej zawsze było traktowane jako istotne i dalej idące, niż wynikałoby to tylko z bezpośredniego brzmienia niektórych jego przepisów. Wystarczy chociażby wskazać na treść dawnego brzmienia art. $131 \mathrm{kc}$. Przepis ten, zarówno przed jego zmianą w 1982 r., jak i po tej zmianie dokonanej nowelizacją kodeksu cywilnego, traktowany był jako wskazówka interpretacyjna określająca sposób kompleksowego rozwiązywania problemów związanych z funkcjonowaniem indywidualnych gospodarstw rolnych, mimo że treść tego przepisu odwoływała się wprost do sposobu interpretacji przepisów kodeksu cywilnego. Przepis art. $131 \mathrm{kc}$. wskazywał bowiem, że „Przy tłumaczeniu i stosowaniu przepisów niniejszego kodeksu należy mieć na względzie, że Polska Rzeczpospolita Ludowa gwarantuje własność i całkowitą ochronę indywidualnych gospodarstw rolnych stanowiących trwały i równoprawny element społeczno-gospodarczego ustroju Polskiej Rzeczypospolitej Ludowej"9. Jak wiadomo, na przyjętą w 1982 r. treść art. 131 kc. istotny wpływ miały przesłanki natury politycznej, wyraźnie zaznaczone w porozumieniach ustrzycko-rzeszowskich z $1981 \mathrm{r}$. Wskazywano, że założenia przyjmowanej wówczas polityki rolnej powinny być wprowadzane w życie m.in. w wydawanych aktach normatywnych oraz w praktyce or-

Ustawa z dnia 13 VII 1957 r. o obrocie nieruchomościami rolnymi (Dz.U. Nr 39, poz. 172 z późn. zm.). Rozp. RM z dnia 28 XI 1964 r. w sprawie przenoszenia własności nieruchomości rolnych, znoszenia współwłasności takich nieruchomości oraz dziedziczenia gospodarstw rolnych (Dz.U. z 1983, Nr 19, poz. 86 z późn. zm.). J.St. Piątowski, (w:) F. Błahuta, J.St. Piątowski, J. Policzkiewicz. Gospodarstwa rolne. Obrót, dziedziczenie, podział, Warszawa 1967, s. 17.

Art. 131 kc. w brzmieniu nadanym ustawą nowelizującą kodeks cywilny z dnia 26111982 r. - por. przypis nr 2 . 
Pojęcia „nieruchomość rolna” i „gospodarstwo rolne” w ujęciu kodeksu cywilnego...

ganów działających w sferze rolnictwa ${ }^{10}$. Nowe brzmienie art. 131 kc., po zmianie kodeksu cywilnego w 1982 r., dało więc asumpt do rozważań dużo szerszych, niż uzasadniałaby to treść przepisu, odnosząca się, jak to już przypomniano, wprost do interpretacji kodeksu cywilnego.

Uwagi te odnoszą się nie tylko do wymowy cytowanego tu przepisu art. $131 \mathrm{kc}$. Na przyjmowane wówczas zmiany w kodeksie cywilnym w części jego „rolnej” regulacji patrzono jako na próbę kompleksowego unormowania szeroko rozumianego obrotu rolnego. S. Wójcik zauważał, że ,szczególna regulacja prawna przeniesienia własności nieruchomości rolnej nie tylko nie może być oderwana od uregulowań innych form szeroko rozumianego obrotu nieruchomościami rolnymi, ale wraz z tymi innymi formami obrotu (zarówno inter vivos, jak i mortis causa) przeniesienie własności powinno tworzyć zwartą całość, spełniając nawet w regulacji prawnej tegoż obrotu jakby rolę wiodącą"11.

Cytowany autor, odnosząc się do treści art. $131 \mathrm{kc}$. wyrażał pogląd, że zgodnie z zapisanymi w tym przepisie ,gwarancjami własności i całkowitą ochroną" indywidualnych gospodarstw rolnych powinny być tłumaczone i stosowane nie tylko przepisy kodeksu cywilnego, ale także inne przepisy prawa, i to zarówno przepisy prawa cywilnego, jak i przepisy innych gałęzi prawa dotyczące indywidualnych gospodarstw rolnych. Z uwzględnieniem tej zasady, jak pisał autor, powinny być także ustanawiane przepisy prawa dotyczące indywidualnych gospodarstw rolnych ${ }^{12}$.

Regulacja kodeksowa dotycząca indywidualnych gospodarstw rolnych odgrywała szczególnie istotną rolę. Wynikało to nie tylko z oczywistego faktu, że obrót nieruchomościami rolnymi regulowany był przepisami kodeksu cywilnego, ale zwłaszcza z tego, że unormowanie tej problematyki w kodeksie cywilnym oznaczało tworzenie prawnych podstaw ochrony własności rolniczej.

Regulacja kodeksowa w tej dziedzinie była równocześnie przedmiotem krytycznych uwag, zwłaszcza - jak przypomina S. Wójcik - w okresie od 4 XI 1971 r. do 5 IV 1982 r. Autor zauważał, że zgłaszane zastrzeżenia dotyczyły zwłaszcza dużej możliwości ingerencji organów administracyjnych w zakresie przeniesienia własności nieruchomości rolnych, przez którą osłabiano ustawowe gwarancje, jakie powinna mieć indywidualna własność rolnicza ${ }^{13}$. Podobnie widział to R. Budzinowski, według którego ,zakres ingerencji państwa w sferę wykonywania prawa własności

10 Por. np. J. Paliwoda, Uwagi o przystosowaniu prawa rolnego do aktualnej polityki rolnej państwa, PiP 1981, z. 2, s. 102; R. Budzinowski, Prawne gwarancje własności i całkowitej ochrony indywidualnych gospodarstw rolnych, PiP 1983, z. 9, s. 87 i n.

11 S. Wójcik, Przeniesienie własności..., op. cit., s. 20.

12 Tamże, s. 21.

13 Tamże, s. 19. 
jest jednym z elementów oceny realizacji własności indywidualnych gospodarstw rolnych"14.

Aczkolwiek więc kodeks cywilny nie zawierał, przed jego zmianą w 1990 r., definicji ,nieruchomości rolnej” czy „,gospodarstwa rolnego”, to normował podstawowe konstrukcje obrotu nieruchomościami rolnymi, i jak już była o tym mowa, wiązał to pojęcie nierozłącznie z zawartym w treści art. $46 \S 1 \mathrm{kc}$. prawnym kryterium własności. Zmiany wprowadzone do kodeksu cywilnego w 1982 r. były, jak to podkreślał R. Budzinowski, wyrazem wzmocnienia gwarancji prawnych dla trwania, w ówczesnej rzeczywistości społeczno-gospodarczej, indywidualnych gospodarstw rolnych, jako formy gospodarowania ${ }^{15}$.

3. Nowelizacja kodeksu cywilnego dokonana w 1990 roku była, jak wiadomo, wyrazem daleko idącej liberalizacji obrotu nieruchomościami rolnymi. Uchylono wówczas dotychczasowe konstrukcje normatywne, które określały podmiotowe i przedmiotowe przesłanki obrotu nieruchomościami rolnymi (art.160, 161, $163 \mathrm{kc}$ ). Można by więc twierdzić, że dotychczasowe rozważania na temat roli i znaczenia kodeksu cywilnego w oddziaływaniu na sferę własności rolniczej były formułowane zbyt optymistycznie, gdyż unormowania kodeksu cywilnego nie odniosły pozytywnego skutku, a rola kc. w tej dziedzinie kształtowania stosunków społecznych była przeceniana. Można by przecież również twierdzić, że gdyby kc. miał odgrywać nadal rolę stabilizującą w odniesieniu do własności rolniczej, to określone jego przepisy dotyczące przeniesienia własności nieruchomości rolnych mogłyby być zmienione w sposób uwzględniający dotychczasowe uwagi krytyczne na ich temat, ale nie być całkowicie eliminowane z kodeksu cywilnego. Sprawa ta budziła zresztą szereg kontrowersji już w momencie dokonywania wspomnianej nowelizacji ${ }^{16}$. Przyjętej w 1990 r. nowelizacji kodeksu cywilnego zarzuca się zwłaszcza, że - jak pisze np. A. Oleszko - wprowadzenie zupełnego liberalizmu, bez zachowania ze strony państwa jakiejkolwiek kontroli co do zachodzących zmian strukturalnych gospodarstw rolnych w zakresie ochrony własności rolniczej, jest przeciwne współczesnym tendencjom prawa państw Unii Europejskiej, których ustawodawstwo w tej części pozostaje pod ścisłą reglamentacją ${ }^{17}$.

Przesłanki przyjęcia w 1990 r. daleko idącej liberalizacji obrotu nieruchomościami rolnymi były już wielokrotnie omawiane w literaturze i nie ma potrzeby szczegółowo ich w tym miejscu przypominać. $\mathrm{Z}$ punktu widzenia prowadzonych tu roz-

\footnotetext{
R. Budzinowski, Prawne gwarancje..., op. cit., s. 91

Tamże, s. 93.

Por. K. Stefańska, Model indywidualnego gospodarstwa rolnego w świetle znowelizowanego kodeksu cywilnego, PiP 1992, z. 3, s. 32 i n. i cyt. tam literatura.

17 A. Oleszko, (w:) Prawo rolne, pod red. A. Stelmachowskiego, Warszawa 2005, s. 116. Krytycznie nt. wspomnianej nowelizacji kc. z 1990 r. por. także A. Lichorowicz, Podstawowe rozwiązania w zakresie obrotu gruntami rolnymi w ustawodawstwie krajów Europy Zachodniej, Studia Prawnicze 1991, z. 3, s. 110; tenże, Kodyfikacja zasad obrotu gruntami rolnymi w nowym szwajcarskim prawie gruntowym, Kwartalnik Prawa Prywatnego 1994, z. 1, s. 67; M. Ptaszyk, Nowe zasady obrotu nieruchomościami rolnymi inter vivos, PiP 1991, z. 7, s. 58.
} 
ważań uzasadnione wydaje się tylko przypomnienie, że w 1990 roku Polska - co oczywiste - nie była jeszcze członkiem UE, nie obowiązywał również Układ Europejski ${ }^{18}$, którego przepis art. 68 zobowiązywał Polskę do dostosowania naszego prawa do prawa wspólnotowego. Fakt, że ustawodawca zrezygnował wtedy z dotychczasowych ograniczeń obrotu nieruchomościami rolnymi zawartych w kodeksie cywilnym, należało widzieć przede wszystkim - tak to odczytuję - jako logiczną konsekwencję trwającego od początku lat 80-tych procesu wzmacniania prawa własności, jego ochrony. Ten kierunek zmian wyraźnie zaznaczał cytowany wcześniej art. $131 \mathrm{kc}$. w brzmieniu nadanym mu nowelizacją kodeksu cywilnego z $1982 \mathrm{r}$. Wyrażone w kodeksie cywilnym przesłanki ekonomiczne związane z ochroną gospodarstwa rolnego zaczęły wówczas ustępować miejsca ochronie własności tych gospodarstw, co nie oznacza, że traciły one na swej ważności. Przyjmowano natomiast inną technikę legislacyjną regulowania tej problematyki, zwłaszcza w drodze pozakodeksowej. Warto $\mathrm{w}$ tym kontekście przypomnieć również dokonaną w 1982 r. zmianę art. 1063 kc., który był wcześniej podstawą prawną dziedziczenia gospodarstwa rolnego przez Skarb Państwa. Uznano, że przesłanki społeczne pozostawienie gospodarstwa rolnego w kręgu rodziny - są istotniejsze niż ekonomiczne, na które wskazywano, uzasadniając możliwość dziedziczenia gospodarstwa rolnego przez Skarb Państwa, gdy ani małżonek, ani nikt spośród krewnych spadkodawcy nie spełniał żadnych szczególnych warunków wymaganych przy dziedziczeniu gospodarstw rolnych ${ }^{19}$. Przepis art. $1063 \mathrm{kc}$. w jego brzmieniu sprzed nowelizacji kodeksu cywilnego w 1982 r. został uznany przez Trybunał Konstytucyjny za niezgodny z konstytucją ${ }^{20}$. TK w cytowanym wyroku podkreślił m.in., że celem przepisu art. 1063 kc. nie było ani uporządkowanie stosunków własnościowych w rolnictwie, ani zachowanie gospodarstwa rolnego jako pewnej całości gospodarczej, ale przejmowanie nieruchomości rolnych przez państwo. Dokonana zmiana treści tego przepisu w 1982 r. wyraźnie potwierdzała dążenie do ochrony własności indywidualnych gospodarstw rolnych.

Wskazywane tu przesłanki dokonanych w 1990 r. zmian w kodeksie cywilnym w części dotyczącej szeroko rozumianego obrotu nieruchomościami rolnymi są na tyle czytelne, że nie wymagają w tym miejscu głębszego ilustrowania ich dalszymi przykładami konkretnych, dokonywanych wtedy zmian zarówno w kodeksie cywilnym, jak i poza nim. Uzasadnione jest jednak podkreślenie, że z punktu widzenia potrzeby szczególnego traktowania gospodarstwa rolnego przez ustawodawcę

Układ Europejski ustanawiający stowarzyszenie między Rzeczapospolitą Polską z jednej strony a Wspólnotami Europejskimi i ich państwami członkowskimi z drugiej strony. Wszedł w życie 1 II 1994 r. (Dz.U. z 1994 r., Nr 11, poz. 38). Opublikowany (w:) Prawo Wspólnot Europejskich. Dokumenty. red. W. Czapliński, R. Ostrihansky i A. Wyrozumska, Warszawa 1997, s. 145 i n. 
jako jednostki produkcji rolnej, jako miejsca pracy, ${ }^{21}$ przyjęte wówczas zmiany mogły budzić i wywoływały określone wątpliwości. A. Lichorowicz wskazywał np., że ,jeśli rolnictwo polskie, jedno z najbardziej rozdrobnionych w Europie, o rosnącej ekstensyfikacji produkcji, ma zapewnić krajowi samowystarczalność żywnościową, ma nie tyle konkurować, co przynajmniej dorównywać przeciętnemu poziomowi europejskiemu, to na dłuższą metę wyłączenie z kompetencji państwa możliwości oddziaływania na strukturę agrarną kraju jest niemożliwe"22.

Przyjmowana regulacja prawna powinna jednak odpowiadać istniejącym w danym czasie uwarunkowaniom, doświadczeniom, mieścić się w specyfice systemu prawnego danego kraju. Nasze doświadczenia związane $\mathrm{z}$ własnością indywidualnych gospodarstw rolnych, a zwłaszcza jej naruszeniami, uzasadniały przyjęcie w 1990 r. wspomnianych zmian w kodeksie cywilnym. A. Stelmachowski przypomina, że indywidualne gospodarstwa rolne poddawane były w przeszłości bądź programowi kolektywizacji, bądź były dyskryminowane poprzez stwarzanie przywilejów dla sektora uspołecznionego. Dopiero, jak zauważa autor, na skutek ruchu „solidarnościowego" w latach 1980/81 doszło do konstytucyjnego zagwarantowania trwałości własności prywatnej w rolnictwie. Natomiast wycofanie się z generalnego programu socjalizacji rolnictwa nastąpiło wraz ze zmianą ustroju w $1989 \mathrm{r}^{23}$

4. Omawiana nowelizacja kodeksu cywilnego z 1990 roku, znosząc dotychczasowe, zawarte w kodeksie cywilnym ograniczenia obrotu nieruchomościami rolnymi, wprowadziła jednocześnie do kodeksu cywilnego - o czym już była mowa pojęcia „nieruchomość rolna” i ,gospodarstwo rolne”, definiując je odpowiednio w art. $461 \mathrm{kc} . \mathrm{i}$ art. $553 \mathrm{kc}$.

Przyjęty zabieg legislacyjny był wyrazem ,zakotwiczenia” problematyki własności rolniczej w prawie cywilnym. Uznając, że kodeks cywilny zawsze był aktem prawnym podstawowym, gdy chodzi o obrót nieruchomościami rolnymi, wskazanie w kodeksie cywilnym zakresu podstawowych pojęć tego obrotu należy przyjąć jako wskazówkę dla sposobu regulowania tej problematyki w innych aktach prawnych. Zmienność materii w tej dziedzinie, determinowana zwłaszcza warunkami natury ekonomicznej, koniecznością dostosowywania naszego prawa do ustawodawstwa europejskiego, założeniami polityki rolnej ${ }^{24}$ uzasadnia udział w regulacji prawnorolnej prawa publicznego. Stwierdzenie to nie dotyczy tylko takich sfer, jak np. prawo ubezpieczeń społecznych, prawo podatkowe, prawo gospodarcze czy finansowe, które ze swej natury regulowane są głównie przez prawo publiczne, ale wspomnia-

W literaturze podkreśla się, że ustawodawca ogranicza uprawnienia związane z własnością rolniczą, aby zapewnić wyżywienie społeczeństwa i aby zachować trwałość rolnych zakładów - por. G. Turner, Agrarrecht. Ein Grundriss, Stuttgart 1994, s. 21. 
na zmienność unormowań prawnych dotyczy także sfery własności rolniczej, obrotu nieruchomościami rolnymi. Zwiększający się także w tej dziedzinie udział prawa publicznego nie może odrywać nas od znaczenia prawa własności. Wieloletnie, najczęściej negatywne doświadczenia w tym zakresie skłaniać powinny do szczególnego dziś akcentowania konieczności ochrony własności rolniczej, wiązania regulacji prawnorolnej z prawem prywatnym. Dlatego też zawarte w kodeksie cywilnym definicje nieruchomości rolnej i gospodarstwa rolnego można traktować jako takie ,wskazanie” dla sposobu regulowania problematyki szeroko rozumianego obrotu nieruchomościami rolnymi także w innych, pozakodeksowych aktach prawnych. Dlatego też trudno podzielić taki pogląd, według którego np. pojęcie nieruchomości rolnej, mimo że zostało zawarte w kodeksie cywilnym (od 1 października 1990 r.), utraciło swe praktyczne znaczenie, a to dlatego, że zliberalizowany został obrót nieruchomościami, które mogły być uznane za rolne ${ }^{25}$. Jak już była o tym wcześniej mowa, kodeks cywilny w części odnoszącej się do problematyki własności gospodarstw rolnych odgrywał dalej idącą rolę, niż wynikałoby to tylko z bezpośredniej interpretacji poszczególnych przepisów. Szczególnie wymowny był w tym zakresie przepis art. $131 \mathrm{kc}$. Podobną wymowę ma, tak to odczytuję, umieszczenie wspomnianych definicji nieruchomości rolnej i gospodarstwa rolnego w kodeksie cywilnym. Zdają się to również potwierdzać używane określenia nieruchomości rolnej i gospodarstwa rolnego zawarte w innych aktach prawnych. Warto zauważyć, że wskazując np. na zakres przedmiotowy ustawy z 19 października $1991 \mathrm{r} .,{ }^{26}$ ustawodawca określił m.in. w jej art. 1, że ,ustawa reguluje zasady gospodarowania mieniem Skarbu Państwa w odniesieniu do: 1) nieruchomości rolnych w rozumieniu Kodeksu cywilnego położonych na obszarach przeznaczonych w planach zagospodarowania przestrzennego na cele gospodarki rolnej...”. Innym przykładem może być treść art. 2 pkt 1 ustawy z dnia 11 kwietnia 2003 r. o kształtowaniu ustroju rolnego ${ }^{27}$, w którym czytamy, że za nieruchomość rolną według u.k.u.r. należy uznać nieruchomość rolną w rozumieniu kodeksu cywilnego, z wyłączeniem nieruchomości położonych na obszarach przeznaczonych w planach zagospodarowania przestrzennego na cele inne niż rolne. Natomiast zgodnie z art. 2 pkt. 2, za gospodarstwo rolne, według tej ustawy należy rozumieć gospodarstwo rolne w rozumieniu kodeksu cywilnego o obszarze nie mniejszym niż 1 ha użytków rolnych. Jak widać więc, punktem odniesienia przy definiowaniu pojęć „,nieruchomość rolna” czy „gospodarstwo rolne" są określenia kodeksowe. Rację ma B. Wierzbowski, gdy stwierdza, że jest potrzebne określenie w u.k.u.r. definicji nieruchomości rolnej, ,aby ustalić zakres przedmiotowy obowiązywania tej ustawy, a w szczególności aby odpowiedzieć

25 Tak B. Wierzbowski, Pojęcie nieruchomości rolnej w prawie polskim, Studia luridica Agraria 2005, t. 4, s. 97; tenże, Gospodarka nieruchomościami. Podstawy prawne, Warszawa 2007, s. 30. 
na pytanie, czy w konkretnym przypadku przeniesienia własności, nieruchomości gruntowej Agencja Nieruchomości Rolnych może wykonać ustawowe prawo pierwokupu, ewentualnie skorzystać ze szczególnego uprawnienia do złożenia nabywcy oświadczenia o nabyciu własności tej nieruchomości (art. 4 ust. 1 u.k.u.r.).”28

Zrozumiałe jest, że w danym akcie prawnym definiuje się podstawowe pojęcia prawne potrzebne dla jego stosowania, określenia zakresu przedmiotowego. W cytowanych tu przykładach zwraca jednak uwagę odwoływanie się przy konstruowaniu poszczególnych definicji do kodeksu cywilnego. Te przykłady zdają się potwierdzać, że kodeks cywilny jest aktem prawnym podstawowym dla regulowania problematyki własności rolniczej. Odwoływanie się do kodeksu cywilnego w cytowanych tu przykładach unormowań prawnych jest wskazaniem na taki sposób ingerowania w prawo własności, czy to przez np. przyjmowanie ustaleń pierwszeństwa nabycia nieruchomości rolnych przez poszczególne podmioty, określanie warunków nabycia tych nieruchomości przy przetargach ofert pisemnych, czy określanie przesłanek wykonania prawa pierwokupu przez dzierżawców nieruchomości rolnych czy ANR, żeby stosując te rozwiązania mieć na uwadze konieczność ochrony własności. Warunki ingerencji muszą więc być precyzyjnie określone w ustawie, gdyż o zakresie przedmiotu własności decyduje ustawa - kodeks cywilny. Tam więc, gdzie ustawodawca odnosi się do problematyki własności rolniczej, jest ścisły związek z kodeksem cywilnym i zakresem pojęć „nieruchomość rolna” i „gospodarstwo rolne”, jako podstawowymi kategoriami pojęciowymi własności rolniczej. T. Kurowska zauważa, że wprowadzone w 1990 roku zmiany do kodeksu cywilnego wzmocniły ochronę majątkowej funkcji prawa własności, ale nie własności rolniczej. Przeciwnie, jak zauważa autorka, znacznie ją osłabiły ${ }^{29}$.

Pogląd ten należy podzielić. W tym kierunku zmierzają także prowadzone w tym opracowaniu rozważania. Zdefiniowanie w kodeksie cywilnym pojęć „nieruchomość rolna" i ,gospodarstwo rolne" wskazują na znaczenie majątkowej funkcji własności, natomiast zawarte w tych definicjach elementy rolne są rozwijane i precyzowane w drodze pozakodeksowej, o czym świadczą cytowane wyżej przykłady, ale kodeks cywilny wyznacza sposób ograniczania funkcji majątkowej własności rolniczej. Trafnie wskazuje Z. Radwański na ważną rolę interpretacyjną, jaką pełnią normy kodeksowe w odniesieniu do norm cywilnoprawnych zawartych w ustawach „Zwykłych”30.

5. W kontekście prowadzonych rozważań uzasadnione jest także odnotowanie treści art. 23 Konstytucji. ${ }^{31}$ Przepis ten stanowi, że „Podstawą ustroju rolne-

28 B. Wierzbowski, Gospodarka nieruchomościami..., op. cit., s. 31.

29 T. Kurowska, Współczesne aspekty własności rolniczej, Studia luridica Agraria 2002, t. 3, s. 43.

30 Z. Radwański, Założenia nowego kodeksu cywilnego, Rejent 2008, z. 2, s. 12. Autor podziela w tym zakresie pogląd wyrażony przez TK w orzeczeniu z dnia 18.10.1994 r., K2/94, OTK 1994, cz. II, poz. 36. Konstytucja RP z dnia 2 IV 1997 r. (Dz.U. Nr 78, poz. 483). 
go państwa jest gospodarstwo rodzinne. Zasada ta nie narusza postanowień art. 21 i art. 22". Nie jest celem tego opracowania podejmowanie bliższej analizy wskazywanego przepisu Konstytucji, którego treść i znaczenie ma już swoje liczne opracowania. ${ }^{32} \mathrm{~W}$ niniejszych rozważaniach uzasadnione wydaje się tylko odnotowanie zawarcia w zd. 2 tego przepisu odesłania do art. 21 i art. 22 Konstytucji. Art. 21 ust. 1 stanowi, że „Rzeczpospolita Polska chroni własność i prawo dziedziczenia”. Natomiast zgodnie z art. 22 „Ograniczenie wolności działalności gospodarczej jest dopuszczalne tylko w drodze ustawy i tylko ze względu na ważny interes publiczny". Warto zauważyć, że uzasadniając sens wprowadzenia do konstytucji przepisu art. 23, w literaturze prawa konstytucyjnego odnotowano zwłaszcza problem gwarancji dla własności indywidualnych gospodarstw rolnych. Jak wskazuje W. Skrzydło, wprowadzenie art. 23 ma konsekwencje prawne, które zobowiązują władze do przestrzegania zasady wskazanej w tym przepisie, wyrażającej się w stanowieniu prawa, które będzie wspierać gospodarstwa rodzinne w dziedzinie gospodarczej, społecznej i finansowej, jak również ochrony interesów właścicieli tych gospodarstw ${ }^{33}$.

Zawarcie w zd. 2 art. 23 Konstytucji stwierdzenia, że zasada wyrażona w zd.1 tego przepisu nie narusza postanowień art. 21 stanowiącego o ochronie własności, odczytać można jako szczególne, konstytucyjne zaznaczenie roli własności przy regulowaniu sytuacji prawnej gospodarstw rodzinnych. Jest to uzasadnione zwłaszcza doświadczeniami z przeszłości, kiedy ta własność była naruszana, albo nie było dla niej stosownych gwarancji wobec forsowanego programu np. kolektywizacji czy peegeryzacji. Dlatego też w treści art. 23 Konstytucji, w zestawieniu jej zwłaszcza z unormowaniem przepisu art. 64 ust. 3 Konstytucji, według którego „Własność może być ograniczona tylko w drodze ustawy i tylko w zakresie, w jakim nie narusza ona istoty prawa własności”, jako pierwszoplanowa wydaje się być sprawa ochrony własności przy regulowaniu sytuacji prawnej gospodarstw rodzinnych. Inaczej akcentuje ten problem A. Lichorowicz, który stwierdza, że w Konstytucji należałoby zamieścić zastrzeżenie, że deklarowana $\mathrm{w}$ jej przepisach ochrona własności może ulec ograniczeniu, jeśli wymaga tego ochrona żywotności oraz gospodarcze umocnienie gospodarstw rodzinnych ${ }^{34}$. Wskazany pogląd może być, jak sądzę, dyskusyjny. Wydaje mi się, że ochrona żywotności gospodarstwa rodzinnego nie powinna uzasadniać ograniczania własności. W hierarchii ważności tych dwóch wartości, ta druga, a więc ochrona własności, w świetle obecnej regulacji konstytucyjnej i dotychczasowych doświadczeń prawnorolnych dotyczących własności rolniczej wymagałaby, w moim przekonaniu, mocniejszego jej akcentowania. Podnoszony

Por. np. A. Lichorowicz, Konstytucyjne podstawy ustroju rolnego RP (w świetle art. 23 Konstytucj), Studia luridica Agraria 2000, t. 1, s. 25 i n.; A. Oleszko, Uznanie rodzinnego gospodarstwa rolnego jako konstytucyjnej podstawy polskiego ustroju rolnego (uwagi do Konstytucji z dnia 2 kwietnia 1997 r.), Rejent 1997, nr 5, s. 79 i n.; T. Kurowska, Gospodarstwo rodzinne czy gospodarstwo rozwojowe. Dylematy wyboru, (w:) Polskie prawo rolne u progu Unii Europejskiej pod red. St. Prutisa, Białystok 1998, s. 109 i n. 
problem wskazuje równocześnie na poszukiwanie takiego sposobu normowania tej problematyki, by prowadzić do harmonizowania obu tych wartości, a nie ich wzajemnego przeciwstawiania. Dodanie w zd. 2 art. 23 Konstytucji zastrzeżenia, że zasada wyrażona w zd. 1 tego przepisu wskazująca na gospodarstwo rodzinne jako podstawę ustroju rolnego państwa nie narusza postanowień m.in. art. 21 Konstytucji, nie jest przypadkowym czy nieprzemyślanym zabiegiem legislacyjnym. Jest to wyraźne wskazanie na potrzebę ochrony własności przy przyjmowaniu regulacji prawnych dotyczących rodzinnych gospodarstw rolnych.

6. Rozważania niniejszego opracowania nie wyczerpują podjętej problematyki. Zasygnalizowanie jej wydawało mi się jednak uzasadnione zwłaszcza w związku z podjętymi pracami legislacyjnymi zmierzającymi do opracowania nowego kodeksu cywilnego ${ }^{35}$. W tym kontekście warto także, jak sądzę, zwrócić uwagę na dotychczasowe prawnorolne aspekty regulacji kodeksowej. Wśród nich obecne w kodeksie cywilnym pojęcia „,nieruchomość rolna” (art. $46^{1} \mathrm{kc}$.) oraz „gospodarstwo rolne” (art. $55^{3} \mathrm{kc}$.) spełniają szczególną rolę w kształtowaniu stosunków własnościowych w rolnictwie, zwłaszcza w rozpoczętym okresie wypracowywania w naszej legislacji modelu gospodarstwa rodzinnego. Art. 23 Konstytucji jest w tym zakresie wyraźnym wskazaniem dla ustawodawcy. Motywy wprowadzenia wspomnianych pojęć do kodeksu cywilnego w wyniku jego nowelizacji w 1990 roku nawiązujące przede wszystkim do potrzeby ochrony własności w odniesieniu do szeroko rozumianego obrotu nieruchomościami rolnymi, nie straciły na aktualności, a jak już wielokrotnie wskazywałam w tym opracowaniu, nabierają one dziś, w związku ze wskazaniami Konstytucji, szczególnego znaczenia. Dlatego też dotychczasowe miejsce wspomnianych definicji w kodeksie cywilnym jest uzasadnione i potrzebne. go, Ministerstwo Sprawiedliwości, Warszawa 2006. 


\section{The ideas of "agricultural real estate" and "agricultural household" in the Civil Code and their significance for agricultural legislation}

\section{Summary}

The fundamental conceptual notions of the Civil Code, such as "agricultural real estate" and "agricultural household" are significant for legal regulation of trading with agricultural properties. The transactions are also regulated in other legal acts, not included in the Civil Code.

The ideas of "agricultural real estate" and "agricultural household", as used in the Civil Code, are referred to the criterion of ownership. This criterion determines the interpretation of particular legal institutions. In respect to the necessity of ownership protection, the notions of "agricultural real estate" and "agricultural household" should exist in the Civil Code, the fundamental legal act for the transfer of ownership of agricultural properties. The introduction of these ideas into the Civil Code in 1990 expressed the tendency to strengthen the agricultural ownership right. The problem of guarantees for ownership is also concerns Article 23 of the Constitution. 